\title{
Assessing the Resistance of Brachiaria Hybrids to Pathogenic Rhizoctonia
}

Elizabeth Alvarez, Michael Latorre, and Ximena Bonilla, Plant Pathology, Guillermo Sotelo, Plant Entomology, and John W. Miles, Plant Breeding, International Center for Tropical Agriculture, Cali, Colombia

\begin{abstract}
Alvarez, E., Latorre, M., Bonilla, X., Sotelo, G., and Miles, J. W. 2014. Assessing the resistance of Brachiaria hybrids to pathogenic Rhizoctonia. Plant Dis. 98:306-310.

Rhizoctonia foliar blight, caused by Rhizoctonia solani anastomosis group 1, is an economically important fungal disease found throughout the world. The fungus attacks numerous crops, including cereals, roots and tubers, legumes, and cruciferous, horticultural, and ornamental plants. In tropical America, this invasive and destructive disease also attacks most Brachiaria spp. used as forages in the ranching industry, especially in the production of cattle. Research to solve this constraint has been ongoing at the International Center for Tropical Agriculture and has generated new Brachiaria hybrids with excellent agronomic

performance, tolerance to poor soils, and, particularly, high resistance to biotic factors such as Rhizoctonia foliar blight. These hybrids belong to lines obtained from Brachiaria humidicola, B. brizantha, and B. decumbens. To identify resistance among Brachiaria hybrid genotypes, the hybrid clones were evaluated for their variability in resistance, and their disease reaction was also determined and characterized. Results led to the identification of hybrids that not only were highly resistant to the blight but also had excellent agronomic characteristics.
\end{abstract}

Rhizoctonia foliar blight, caused by Rhizoctonia solani, is a destructive disease of forage grasses that are commercially important in Latin America. In highly intensive production systems in Colombia, Rhizoctonia foliar blight disease can cause foliar damage and significant biomass losses. When sufficient moisture is present, Rhizoctonia spp. spread from plant to plant through the growth of hyphae among plant leaves. Rhizoctonia spp. have the ability to survive in the soil for long periods of time. Due to this fact, susceptible plants should not be planted in previously infected and problematic sites. Rhizoctonia foliar blight management has relied on the application of fungicides. Host resistance is the most economical and environmentally sound strategy to manage Rhizoctonia foliar blight. Cattle-raising on ranches in tropical and subtropical Latin America is a major economic activity and employs a highly significant fraction of the land in every agroecosystem found in each country. It is an important source of rural employment and income, especially for small and medium-sized double-purpose farms (i.e., beef and dairy; 18). According to Rippestein et al. (17), $45 \%$ of tropical savannas in Latin America are used for this activity; that is, about $20 \%$ of the region's land surface. In Colombia, $91 \%$ of the total area available for agriculture is under pasture; in Central America, $73 \%$ (7).

The genus Brachiaria (family Paniceae) includes approximately 100 species distributed throughout the tropics, especially in Africa but also in Asia, Australia, and North and South America (16). In particular, the perennial species Brachiaria arrecta, B. brizantha, $B$. decumbens, $B$. dictyoneura, B. humidicola, B. mutica, and B. ruziziensis $(2,13)$ are used as pastures on more than 70 million hectares of land in tropical America (13). They are also used on a smaller scale on farms in Asia, the South Pacific, and Australia (21).

A major problem confronting regional livestock production is the pastures' susceptibility to pests and diseases. Rhizoctonia foliar

Corresponding author: E. Alvarez, E-mail: ealvarez@cgiar.org

All authors have reviewed the manuscript and approved its submission to Plant Disease. The manuscript is not being submitted elsewhere.

Accepted for publication 28 August 2013.

http://dx.doi.org/10.1094/PDIS-04-13-0405-RE

(c) 2014 The American Phytopathological Society blight has acquired significant importance in tropical America, and is estimated to be the most devastating disease of ranches and farms when large areas are planted with only one cultivar of $\mathrm{Bra}$ chiaria $(1,10,22)$.

Rhizoctonia foliar blight is an invasive and destructive disease caused by the fungal pathogen $R$. solani. This pathogen is found throughout the world, causing diverse and devastating diseases in a wide variety of crops such as rice (Oryza sativa), potato (Solanum tuberosum), soybean (Glycine max), sorghum (Sorghum bicolor), sugarcane (Saccharum spp.), strawberry (Fragaria spp.), maize (Zea maize), tomato (Solanum lycopersicum), bean (Phaseolus vulgaris), canola (Brassica napus), and ornamental plants $(6,11)$.

Rhizoctonia spp. attack most Brachiaria cultivars. Up to $50 \%$ of Brachiaria production in the tropics is affected by Rhizoctonia foliar blight (1). In Colombia, the incidence and severity of Rhizoctonia foliar blight is very high in some areas, especially in the Eastern Plains (12). Brachiaria grasses, because of their wide adaptability, tolerance of low-fertility acid soils, and high levels of productivity, present a partial solution to this problem, compared with other forage materials. Pasture research, carried out by the International Center for Tropical Agriculture (CIAT) and numerous national institutions beginning in the 1980s to the present, has given rise to new Brachiaria hybrids. These hybrids have been introduced into livestock production systems of tropical Latin America with success in many areas.

Despite their advantages, Brachiaria grasses present limitations: for example, they have low tolerance to intense and prolonged dry seasons and are highly susceptible to diseases such as those caused by Rhizoctonia spp. and pests such as the cercopids; specifically, the spittlebugs (also called froghoppers) $(10,14,15)$. These limitations can cause economic losses. In tackling these challenges, recent research on improving the Brachiaria genus has concentrated on obtaining a new generation of hybrids that have outstanding agronomic characteristics, good establishment vigor, high capacity for reshooting, superior yields, high nutritive quality, good seed production, and resistance to Rhizoctonia foliar blight.

The objective of this study was to identify new Brachiaria hybrids with high resistance to Rhizoctonia foliar blight. These hybrids tested belonged to lines obtained from Brachiaria humidicola (BH08NO), B. brizantha, and B. decumbens (INRZ10). In searching for durable resistance among the Brachiaria hybrids, resistance of Brachiaria hybrids was evaluated under greenhouse conditions using $R$. solani isolates obtained from different geographical zones. In addition, isolate-genotype interactions were determined (1). 


\section{Materials and Methods}

This study was conducted in the laboratories and greenhouses of Forage Pathology at CIAT, Palmira, Colombia.

Plant materials and growing conditions. Tillers that were 20 to $25 \mathrm{~cm}$ tall were detached from their mother plants. All parts of the plant except for the flag leaf were then trimmed. To reduce contamination, the plant materials were immersed for $5 \mathrm{~min}$ in a $1 \%$ solution of sodium hypochlorite in distilled water. Tillers (clones) were then planted individually in 5.3-by-6.5-cm PVC tubes containing $36 \mathrm{~g}$ of sterilized soil (nursery mixture of soil/soil/sand in a 4:1:1 ratio) $(1,4)$. The plants were grown in a

Table 1. Rhizoctonia isolates from Colombia used to inoculate Brachiaria genotypes

\begin{tabular}{|c|c|c|}
\hline Isolate code & Location & Host \\
\hline $8-167(2)$ & Puerto López, Meta & Hybrid 'Mulato II' \\
\hline $8-168(1)$ & Puerto López, Meta & Hybrid Mulato II \\
\hline $8-197(1)$ & Yopal, Casanare & Hybrid Mulato II \\
\hline $9-032(1)$ & Sahagún, Córdoba & Brachiaria brizantha 'Toledo' \\
\hline $9-098(2)$ & Cereté, Córdoba & B. decumbens \\
\hline $9-193(1)$ & Florencia, Caquetá & B. decumbens \\
\hline $9-221(1)$ & Florencia, Caquetá & B. mutica \\
\hline $10-031(1)$ & Puerto López, Meta & Hybrid Mulato II \\
\hline $10-031(2)$ & Puerto López, Meta & Hybrid Mulato II \\
\hline A-36061 & Florencia, Caquetá & Hybrid 'Mulato' \\
\hline
\end{tabular}

clean greenhouse until assays were conducted on 40-day-old clonal transplants incubated at $28^{\circ} \mathrm{C}$ and $80 \%$ relative humidity. Plants were fertilized 1 week before inoculation and watered every two days.

Isolates and inoculum preparation. Isolates belonging to the $R$. solani anastomosis group 1 and intraspecific group IA ( $R$. solani AG 1-IA) were obtained from different infected Brachiaria genotypes sampled in the field on 2009 and 2010 in the departments of Meta, Casanare, Córdoba, and Caquetá. These monothallic isolates were maintained (long-term) on filter paper in the dark at $20^{\circ} \mathrm{C}$, according to the methodology described by Aricapa and Correa (3), before the inoculation studies. Different methods of inoculation were tried, including spray and stem inoculation, but the superior method chosen was stem inoculation (1). Various levels and types of inocula (e.g., sclerotium and mycelium) were also previously evaluated to determine which inocula produced the most reliable results. In this case, inoculum preparation involved growing the individual fungal isolates for 8 days on potato dextrose agar medium that was supplemented with amoxicillin (at a rate of 300 $\mathrm{mg} / \mathrm{liter}$ ).

For inoculation itself, a 4-mm disk of mycelium on agar was placed at the point of union between the stem and leaf blade of each of the lowest (oldest) two leaves of each plant; no additional wounding was necessary. The controls were inoculated with just an agar plug. Individual inoculated plants (experimental units), including the controls, were incubated under greenhouse conditions at $28^{\circ} \mathrm{C}$. The aboveground portion of each plant was enclosed in a

Table 2. Evaluating the resistance of Brachiaria hybrids to Rhizoctonia isolates, trial $1^{\mathrm{a}}$

\begin{tabular}{|c|c|c|c|c|c|c|c|c|c|c|c|}
\hline \multirow[b]{2}{*}{ Isolates } & \multicolumn{10}{|c|}{ Hybrid genotypes } & \multirow[b]{2}{*}{$\mu$} \\
\hline & $\begin{array}{l}\text { INRZ10/ } \\
017\end{array}$ & $\begin{array}{c}\text { INRZ10/0 } \\
20\end{array}$ & $\begin{array}{c}\text { INRZ10/0 } \\
40\end{array}$ & $\begin{array}{l}\text { INRZ10/ } \\
080\end{array}$ & $\begin{array}{c}\text { BR09NO/ } \\
1183\end{array}$ & $\begin{array}{c}\text { BR09NO/ } \\
3407\end{array}$ & $\begin{array}{c}\text { BR09NO/ } \\
4438\end{array}$ & $\begin{array}{c}\text { BR09NO/ } \\
6812\end{array}$ & $\begin{array}{c}\text { CIAT } \\
\text { 16320 }^{b}\end{array}$ & Mulato & \\
\hline $8-167(2)$ & 1.71 & 1.72 & 1.48 & 2.69 & 6.00 & 4.36 & 6.79 & 4.54 & 1.49 & 4.76 & 3.55 \\
\hline $8-168(1)$ & 0.73 & 0.83 & 1.63 & 1.17 & 4.47 & 1.40 & 2.18 & 4.75 & 1.42 & 2.07 & 2.06 \\
\hline 8-197(1) & 3.00 & 1.51 & 2.39 & 1.51 & 6.34 & 4.69 & 8.05 & 5.88 & 1.55 & 7.19 & 4.21 \\
\hline $9-032(1)$ & 2.12 & 0.67 & 3.27 & 0.67 & 5.93 & 4.28 & 5.54 & 6.20 & 1.07 & 5.89 & 3.56 \\
\hline $9-098(2)$ & 1.84 & 1.68 & 0.84 & 0.58 & 4.33 & 2.30 & 4.01 & 5.11 & 0.59 & 5.66 & 2.69 \\
\hline 9-193(1) & 0.13 & 0.11 & 0.14 & 0.77 & 0.66 & 1.48 & 3.71 & 4.93 & 0.46 & 2.55 & 1.49 \\
\hline $9-221(1)$ & 0.76 & 0.39 & 0.49 & 0.13 & 2.94 & 3.24 & 3.58 & 5.61 & 1.14 & 3.39 & 2.17 \\
\hline $10-031(1)$ & 0.11 & 0.46 & 0.74 & 0.49 & 1.84 & 2.10 & 3.11 & 2.00 & 0.25 & 2.44 & 1.35 \\
\hline $10-031(2)$ & 1.25 & 1.50 & 3.06 & 1.67 & 4.01 & 3.95 & 5.75 & 5.50 & 1.96 & 5.46 & 3.41 \\
\hline A-36061 & 2.61 & 0.71 & 0.90 & 0.35 & 3.83 & 1.88 & 4.83 & 5.55 & 0.76 & 4.02 & 2.54 \\
\hline Control $^{c}$ & 0.00 & 0.00 & 0.00 & 0.00 & 0.00 & 0.00 & 0.00 & 0.00 & 0.00 & 0.00 & 0.00 \\
\hline$\mu$ & 1.30 & 0.87 & 1.36 & 0.91 & 3.67 & 2.70 & 4.32 & 4.55 & 0.97 & 3.95 & $\ldots$ \\
\hline
\end{tabular}

${ }^{a}$ Data are expressed as units of area under the disease progress curve (AUDPC) and refer to adjusted means of treatments for AUDPC results based on natural $\log$ transformation. Least significance differences (LSD) value $=0.113$ and $P=0.05$.

b International Center for Tropical Agriculture (CIAT) 16320 (Brachiaria brizantha) was the resistant control.

c True control (inoculated with an agar plug).

Table 3. Evaluating the resistance of Brachiaria hybrids to Rhizoctonia isolates, trial $2^{\text {a }}$

\begin{tabular}{|c|c|c|c|c|c|c|c|c|c|c|c|}
\hline \multirow[b]{2}{*}{ Isolate } & \multicolumn{10}{|c|}{ Hybrid genotypes } & \multirow[b]{2}{*}{$\boldsymbol{\mu}$} \\
\hline & $\begin{array}{c}\text { BH08NO/ } \\
0066\end{array}$ & $\begin{array}{c}\text { BH08NO/ } \\
\mathbf{0 3 7 5}\end{array}$ & $\begin{array}{c}\text { BH08NO/ } \\
0403\end{array}$ & $\begin{array}{c}\text { BH08NO/ } \\
0679\end{array}$ & $\begin{array}{c}\text { BH08NO/ } \\
1199\end{array}$ & $\begin{array}{c}\text { BH08NO/ } \\
1212\end{array}$ & $\begin{array}{c}\text { BH08NO/ } \\
1261\end{array}$ & $\begin{array}{l}\text { CIAT } \\
00679\end{array}$ & $\begin{array}{c}\text { CIAT } \\
06133\end{array}$ & $\begin{array}{c}\text { CIAT } \\
\text { 16868 }^{b}\end{array}$ & \\
\hline $8-167(2)$ & 1.17 & 5.15 & 1.11 & 1.75 & 2.24 & 3.13 & 1.57 & 4.51 & 1.27 & 1.53 & 2.34 \\
\hline $8-168(1)$ & 1.11 & 3.43 & 0.77 & 1.21 & 3.03 & 3.10 & 1.70 & 1.87 & 0.97 & 1.28 & 1.85 \\
\hline 8-197(1) & 1.48 & 4.86 & 0.69 & 2.14 & 2.58 & 1.86 & 1.47 & 2.49 & 1.27 & 1.45 & 2.03 \\
\hline $9-032(1)$ & 0.89 & 3.42 & 0.39 & 3.48 & 1.80 & 3.02 & 1.17 & 3.56 & 1.06 & 0.92 & 1.97 \\
\hline $9-098(2)$ & 1.01 & 4.37 & 0.70 & 2.31 & 1.70 & 1.92 & 1.72 & 3.33 & 1.48 & 1.26 & 1.93 \\
\hline $9-193(1)$ & 1.48 & 4.95 & 1.69 & 1.37 & 3.15 & 2.62 & 1.66 & 2.08 & 0.69 & 0.80 & 2.06 \\
\hline $9-221(1)$ & 1.16 & 6.25 & 0.97 & 2.73 & 3.50 & 3.40 & 1.90 & 3.63 & 0.83 & 1.34 & 2.57 \\
\hline $10-031(1)$ & 1.00 & 4.78 & 1.40 & 2.08 & 3.40 & 2.20 & 2.18 & 3.76 & 1.53 & 0.98 & 2.33 \\
\hline $10-031(2)$ & 1.29 & 6.88 & 0.94 & 2.52 & 3.66 & 4.27 & 2.40 & 3.54 & 1.10 & 2.16 & 2.88 \\
\hline A-36061 & 1.17 & 5.56 & 1.18 & 1.71 & 2.28 & 3.47 & 2.71 & 3.97 & 1.03 & 1.43 & 2.45 \\
\hline Control $^{\mathrm{c}}$ & 0.00 & 0.00 & 0.00 & 0.00 & 0.00 & 0.00 & 0.00 & 0.00 & 0.00 & 0.00 & 0.00 \\
\hline$\mu$ & 1.07 & 4.51 & 0.89 & 1.93 & 2.48 & 2.63 & 1.68 & 2.98 & 1.02 & 1.19 & $\ldots$ \\
\hline
\end{tabular}

${ }^{\text {a }}$ Data are expressed as units of area under the disease progress curve (AUDPC) and refer to adjusted means of treatments for AUDPC results based on natural $\log$ transformation. Least significance differences (LSD) value $=0.0806$ and $P=0.05$.

${ }^{\mathrm{b}}$ International Center for Tropical Agriculture (CIAT) 16868 (Brachiaria humidicola) was the resistant control.

c True control (inoculated with an agar plug). 
600-ml, clear-plastic water bottle. The bottle acted as a microchamber to create conditions of high relative humidity (80 to $100 \%$ ). It also physically isolated each individual plant, preventing leaf contact between adjacent plants $(4,5,8,20)$. Details of the production of microchambers are described by Cardona et al. (5) but were modified in our study by reducing the size of the bottle and the number of ventilation holes from 250 to 20 (1).

Virulence study. Pathogen virulence was evaluated by inoculating 20 Brachiaria hybrids in two experiments (10 hybrids in each experiment), each with 10 different fungal isolates plus a control (inoculated with an agar plug; Tables 1-3). Isolates were selected from 147 isolates collected in a previous study (1) chosen for diversity of geographic origin, growth rate, isolate color, original host, nuclear condition (number of nuclei per cell), and virulence. A split-plot experimental design was used, where isolates were assigned to main plots and host genotypes to the subplots. Each isolate-host genotype combination was replicated five times to obtain 550 subplot experimental units (plants). The experiment was conducted twice.

The inoculated plants were evaluated every 3 days for 15 to 18 days to record disease progress. A visual scale of 0 to 5 was used, following Alvarez (1), where a score of 0 signified no disease, 1 corresponded to 0.1 to $0.9 \%$, of the leaf surface area infected, $1.5=1$ to $11.9 \%$ infection, $2=12$ to $24.9 \%$ infection, $2.5=25$ to $36.9 \%$ infection, $3=37$ to $49.9 \%$ infection, $3.5=50$ to $61.9 \%$ infection, $4=$ 62 to $86.9 \%$ infection, $4.5=87$ to $99.9 \%$ infection, and $5=100 \%$ infection. The plant's surface area (leaves and stems) was measured and compared with the lesion area to determine percentage infection. The methodology's reliability has been previously verified (1).

Data on disease severity were used to calculate the area under the disease progress curve (AUDPC).

$$
\operatorname{AUDPC}=\sum_{i=1}^{n}\left(\frac{X_{i}+X_{i-1}}{2}\right)\left(t_{i}-t_{i-1}\right)
$$

where $X_{i}=$ severity of disease in the $i$ th evaluation $\left(X_{0}=0\right), t_{i}=$ time in days from inoculation to the $i$ th evaluation $\left(t_{0}=0\right)$, and $n=$ number of evaluations.

Values obtained for each experimental unit (individual plant clone) were submitted to an analysis of variance to assess differences among host genotypes and the magnitude of the interaction between isolate and host. The Ryan-Einot-Gabriel-Welsch multiple range test was then used to separate groups of isolates that differed in disease severity. For statistical analysis, AUDPC data were transformed, using the natural logarithm function to meet the assumptions of normality and homogeneity of variance.

Trial 1. The Brachiaria hybrids evaluated as clonal genotypes in the first trial were of $B$. brizantha origins: INRZ10/017, INRZ10/020, INRZ10/040, INRZ10/080, BR09NO/1183, BR09NO/3407, BR09NO/4438, and BR09NO/6812; as well as $B$. brizantha CIAT 16320; and Brachiaria hybrid 'Mulato' (CIAT 36061) as a susceptible control.

Trial 2. The Brachiaria hybrids evaluated as clonal genotypes in second trial were of $B$. humidicola origin: $\mathrm{BH} 08 \mathrm{NO} / 0066$,
BH08NO/0375, BH08NO/0403, BH08NO/0679, BH08NO/1199, BH08NO/1212, and BH08NO/1261; B. humidicola 'Tully' (CIAT 00679); B. humidicola (CIAT 06133); and B. humidicola (CIAT 16868) as a resistant control. Both of these trials were repeated twice.

The data analysis for the virulence assessments was conducted with SAS System software v. 9.0 for UNIX (19); specifically, using the MIXED procedure and REML estimation method (which calculates the errors adjusted to all comparisons).

\section{Results}

Virulence study. The artificial inoculation methodology used in this study imposed a disease pressure that allowed reliable evaluation of host reactions and the virulence of pathogenic isolates (1). The methodology's reliability was previously verified by Cardona et al. (4) and results reported here are based on stem inoculation with mycelial plugs from freshly grown inocula per isolate.

Individual host reactions to different isolates, expressed as AUDPC, can be compared in Tables 2 and 3. Significance was demonstrated for the main effects: host genotype, fungal isolate, and their interactions (Table 4).

Increased resistance to the pathogen was observed for the hybrids INRZ10/020, INRZ10/080, INRZ/017, and INRZ10/040 (generated from $B$. brizantha and $B$. decumbens and used in trial 1); and for hybrids BH08NO/0403, BH08NO/0066, CIAT 06133, $\mathrm{BH} 08 \mathrm{NO} / 1261, \mathrm{BH} 08 \mathrm{NO} / 0679$, BH08NO/1199, and BH08NO/1212 (generated from $B$. humidicola and used in trial 2) (Table 3). These genotypes contrasted with the susceptible hybrids BR09NO/6812, BR09NO/4438, BR09NO/1183 (trial 1), and BH08NO/0375 (trial 2).

Results suggest significant diversity among the isolates in terms of virulence against the hybrids evaluated and, more generally, the presence of differential reactions among the hybrids when challenged with the Rhizoctonia isolates used.

Overall, results showed that some Brachiaria hybrids used in the present study were resistant to the Rhizoctonia foliar blight isolates analyzed. To illustrate the type of resistance found, a figure of trial 1 is shown, in which the resistance versus the susceptibility of the Brachiaria hybrids can be observed (Fig. 1). This figure shows the reaction of genotypes 7 (BR09NO/4438, susceptible in trial 1) and 4 (INRZ/080, resistant) to Rhizoctonia isolates from different sites in Colombia, compared with the noninoculated control.

\section{Discussion}

The results also showed significant differences among isolates, genotypes, and isolate-host genotype interaction for both trials (Table 4). The differences between the two trials lay principally in the virulence or aggressiveness of the Rhizoctonia isolates toward the Brachiaria genotypes evaluated (Tables 2 and 3). The differences among Brachiaria genotypes in their reactions to the isolates evaluated were much greater than the differences among isolates or among isolate-host genotype interactions (Tables 2 and 3).

The isolate-genotype interaction was significant but, when compared with the main effect of genotypes and of isolates, the effects

Table 4. Analysis of variance of the area under disease progress curve of Rhizoctonia isolates inoculated on Brachiaria hybrids for the virulence study

\begin{tabular}{|c|c|c|c|c|c|}
\hline Source of variation & DF & Sum of squares & Mean squares & $F$ value & $\operatorname{Pr}>F$ \\
\hline \multicolumn{6}{|l|}{ Trial 1} \\
\hline Replicate & 4 & 0.58 & 0.14 & 2.77 & 0.03 \\
\hline Isolate & 10 & 150.46 & 15.04 & 289.22 & $<0.0001$ \\
\hline Replicate $\times$ isolate & 40 & 2.34 & 0.06 & 1.12 & 0.29 \\
\hline Genotype & 9 & 89.02 & 9.89 & 190.14 & $<0.0001$ \\
\hline Isolate $\times$ genotype & 90 & 53.14 & 0.59 & 11.35 & $<0.0001$ \\
\hline \multicolumn{6}{|l|}{ Trial 2} \\
\hline Replicate & 4 & 0.41 & 0.10 & 2.23 & 0.07 \\
\hline Isolate & 10 & 92.16 & 9.22 & 199.2 & $<0.0001$ \\
\hline Replicate $\times$ isolate & 40 & 1.26 & 0.03 & 0.68 & 0.93 \\
\hline Genotype & 9 & 55.26 & 6.14 & 132.70 & $<0.0001$ \\
\hline Isolate $\times$ genotype & 90 & 24.12 & 0.27 & 5.79 & $<0.0001$ \\
\hline
\end{tabular}


of interactions were minimal. However, differences among interactions were significant in both trials, illustrating the fact that, even though large advances were made in the resistance obtained, absolute horizontal resistance had not been achieved. For more durable resistance, not having an isolate-genotype interaction is desirable. However; the resistances of many $B$. humidicola hybrids appear to be effective against the majority of isolates for the most part, with the exception of genotype 2 (BH08NO/0375), which was susceptible while all others in trial 2 were more resistant.

Significance in plant-pathogen interaction shows that each genotype evaluated reacts differently to each Rhizoctonia isolate used, which would give importance to the variability of the pathogens and their relation to the environments from which they were collected.
The main finding of our study was that highly resistant hybrids have been generated and that they were very close to possessing horizontal resistance. Researchers have found a good association between resistance found in the greenhouse with the screening methodology used and the resistance observed under natural disease pressure in the field. Although disease levels were moderately higher in the greenhouse than in the field, they correlated positively (9). Reliability of the methodology presented here was determined previously (1).

On the basis of previous research on the performance of the evaluated genotypes, some materials have already been classified according to their reactions to $R$. solani under greenhouse conditions. In this sense, Kelemu (9) reported resistance in B. humidicola, such as genotypes CIAT 16868, CIAT 16886, CIAT
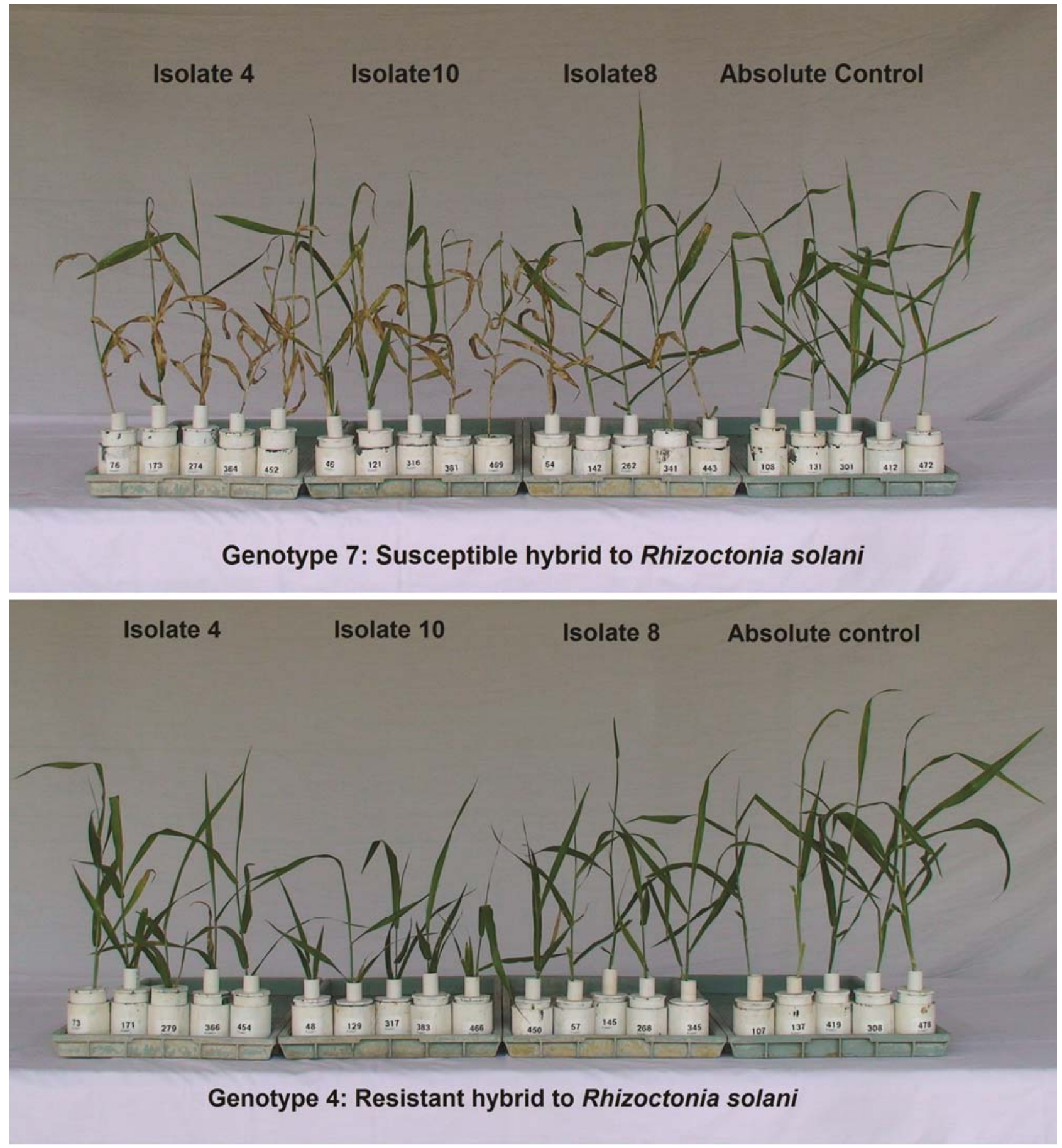

Fig. 1. Reaction of hybrids 7 (BR09NO/4438, susceptible in trial 1) and 4 (INRZ/080, resistant) when inoculated with Rhizoctonia isolates from different sites in Colombia, compared with the noninoculated control. Isolate 4 is from Córdoba; isolate 10 from Caquetá; and isolate 8 from Meta. High resistance was obtained, as shown in the reaction of hybrid INRZ10/080 to Rhizoctonia foliar blight. Genotype 7: hybrid susceptible to Rhizoctonia solani. Genotype 4: hybrid highly resistant to $R$. solani. 
6369, and CIAT 6133 ('Llanero') as highly resistant and genotypes CIAT 679, CIAT 16876, CIAT 16887, CIAT 16888, and CIAT 16320 as moderately resistant. Some of these genotypes were also evaluated in our study with similar findings. B. humidicola hybrids have great potential for genes for resistance. Our study also demonstrated that hybrids belonging to the INRZ10 and BH08NO lines showed resistance to different Rhizoctonia isolates collected from various cattle-raising zones of Colombia. These taxa may be useful in a breeding program to increase plant resistance against this disease.

The farmer must evaluate basic criteria when selecting which cultivar to use, depending on environmental conditions and the livestock's requirements. These criteria may be more important than the simple fact that the genotype is resistant to the disease. In other words, genotypes resistant to one disease in a given environment may not be effective in another environment where strong disease pressure exists or a different race of pathogen is found.

In summary, hybrids highly resistant to Rhizoctonia foliar blight were identified. This advance is expected to lead to the acquisition of materials that will offer increased productivity and have a wider range of adaptation. Likewise, through the adoption of new Brachiaria cultivars, the economic and social situation of many groups of small or medium farmers can be improved as livestock production is developed and modernized. As well as mitigating negative impact on the environment, by reducing fungicide use, these cultivars can help shift the industry from being based on extensive to intensive production models. The new hybrids produce significantly more forage fiber per unit area than the previous species used.

It is of importance that those hybrids of the species $B$. brizantha tended to be more susceptible whereas those of the species $B$. humidicola were more resistant. This is a significant finding with implications for breeding for resistance. Most hybrids developed with the species $B$. humidicola exhibit resistance to most isolates tested. This taxa could be useful in breeding programs to increase plant resistance against Rhizoctonia foliar blight. Rhizoctonia isolates from Brachiaria hybrids 9-221(1) and A-36061 caused reaction in most of the Brachiaria materials evaluated in previous experiments, and they could be of use as highly virulent isolates in future experiments to evaluate resistance to Rhizoctonia foliar blight. The breeder must also consider that, before introducing genotypes that were earlier identified as resistant, they should be validated under farming conditions to confirm their performance, because there is no way of being sure that a cultivar is resistant to all variants of a population of pathogens that exist now or could arise in the future. Additional research may reveal variants, or races of $R$. solani, able to severely attack a cultivar previously thought to be horizontally-resistant.

\section{Literature Cited}

1. Alvarez, E., Latorre, M. Bonilla, X.., Sotelo, G., and Miles, J. W. 2013. Diversity of Rhizoctonia spp. causing foliar blight on Brachiaria in Colombia and evaluation of Brachiaria genotypes for foliar blight resistance. Plant Dis. 97:772-779.

2. Argel, P. J., and Keller-Grein, G. 1996. Regional experience with Brachiaria: tropical America-humid lowlands. Pages 164-177 in: Brachiaria: Biology, Agronomy, and Improvement. J. W. Miles, B. L. Maass, C. B. do Valle, and V. Kumble, eds. Centro Internacional de Agricultura Tropical (CIAT) and Centro Nacional de Pesquisa de Gado de Corte (CNPGC) of Empresa Brasileira de Pesquisa Agropecuária (EMBRAPA), Cali, Colombia.

3. Aricapa, M. G., and Correa, F. 1994. Almacenamiento de hongos en papel filtro. Ascolfi Inf. 20:29-30.

4. Cardona, C., Miles, J. W., and Sotelo, G. 1999. An improved methodology for massive screening of Brachiaria spp. genotypes for resistance to Aene- olamia varia (Homoptera: Cercopidae). J. Econ. Entomol. 92:490-496.

5. Cardona, C., Miles, J. W., Zúñiga, E., and Sotelo, G. 2010. Independence of resistance in Brachiaria spp. to nymphs or to adult spittlebugs (Hemiptera: Cercopidae): implications for breeding for resistance. J. Econ. Entomol. 103:1860-1865.

6. Dolores, G. H. 2002. Estado actual de la taxonomía de Rhizoctonia solani Kuhn. Rev. Mex. Fitopatol.200:200-205.

7. FAO (Food and Agriculture Organization of the United Nations). 2004 FAOSTAT. http://faostat.fao.org/

8. Jia, Y., Correa-Victoria, F., McClung, A., Zhu, L., Liu, G., Wamishe, Y., Xie, J., Marchetti, M. A., Pinson, S. R. M., Rutger, J. N., and Correll, J. C. 2007. Rapid determination of rice cultivar responses to the sheath blight pathogen using a micro chamber screening method. Plant Dis. 91:485-489.

9. Kelemu, S., Miles, J. W., Bonilla, X. P., and Badel, J. L. 1995. Sources of resistance in species of Brachiaria to foliar blight disease caused by $R h i$ zoctonia solani. Trop. Grassl. 29:257-262.

10. Miles, J. W., Maass, B. L., do Valle, C. B., and Kumble, V., eds. 1996. Brachiaria: Biology, Agronomy, and Improvement. Centro Internacional de Agricultura Tropical and Centro Nacional de Pesquisa de Gado de Corte (CNPGC) of Empresa Brasileira de Pesquisa Agropecuária (EMBRAPA), Cali, Colombia.

11. Parmeter, J. R., Jr. 1970. Rhizoctonia solani: Biology and Pathology. University of California Press, Berkeley.

12. Peters, M., Franco, H. L., Schmidt, A., and Hincapie, B. 2011. Especies Forrajeras Multipropósito: Opciones para Productores del Trópico Americano. Centro Internacional de Agricultura Tropical (CIAT), Cali, Colombia.

13. Pizarro, E. A., do Valle, C. B., Keller-Grein, G., Schultze-Kraft, R., and Zimmer, A. H. 1996. Natural variation in Brachiaria and existing germplasm collections. Pages 164-177 in: Brachiaria: Biology, Agronomy, and Improvement. J. W. Miles, B. L. Maass, C. B. do Valle, and V. Kumble, eds. Centro Internacional de Agricultura Tropical (CIAT) and Centro Nacional de Pesquisa de Gado de Corte (CNPGC) of Empresa Brasileira de Pesquisa Agropecuária (EMBRAPA), Cali, Colombia.

14. Rao, I. M., Kerridge, P. C., and Macedo, M. 1996. Nutritional requirements of Brachiaria and adaptation to low-fertility acid soils. Pages 53-71 in: Brachiaria: Biology, Agronomy, and Improvement. J. W. Miles, B. L. Maass, C. B. do Valle, and V. Kumble, eds. Centro Internacional de Agricultura Tropical (CIAT) and Centro Nacional de Pesquisa de Gado de Corte (CNPGC) of Empresa Brasileira de Pesquisa Agropecuária (EMBRAPA), Cali, Colombia.

15. Rao, I. M., Zeigler, R. S., Vera, R., and Sarkarung, S. 1993. Selection and breeding for acid soil tolerance in crops: upland rice and tropical forages as case studies. BioScience 43:454-465.

16. Renvoize, S. A., Clayton, W. D., and Kabuye, C. H. S. 1996. Pages 164-177 in: Brachiaria: Biology, Agronomy, and Improvement. J. W. Miles, B. L. Maass, C. B. do Valle, and V. Kumble, eds. Centro Internacional de Agricultura Tropical (CIAT) and Centro Nacional de Pesquisa de Gado de Corte (CNPGC) of Empresa Brasileira de Pesquisa Agropecuária (EMBRAPA), Cali, Colombia.

17. Rippstein, G., Amézquita, E., Escobar, G., and Grollier, C. 2001. Condiciones naturales de la sabana. Pages 1-21 in: Agroecología y biodiversidad de las sabanas en los Llanos Orientales de Colombia. G. Rippstein, G. Escobar, and F. Motta, eds. Centro Internacional de Agricultura Tropical (CIAT) and Centre de Coopération Internationale en Recherche Agronomique pour le Développement (CIRAD), Cali, Colombia.

18. Rivas, L., and Holmann, F. 2004. Impacto de la adopción de híbridos de Brachiaria en México y Centroamérica. Centro Internacional de Agricultura Tropical (CIAT), Cali, Colombia.

19. SAS Institute, Inc. 2004. What's New in SAS 9.0, 9.1, 9.1.2. Cary, NC.

20. Sneh, B., Jabaji-Hare, S., and Dijst, G. 1996. Rhizoctonia Species: Taxonomy, Molecular Biology, Ecology, Pathology and Disease Control. Kluwer Academic Publishers, Dordrecht, The Netherlands.

21. Sotelo, G., Segura, G., Bonilla, J., and Miles, J. W. 2007. Develop and refine a robust, high throughput screening methodology for reaction to $R h i$ zoctonia solani, based on greenhouse-grown plants and artificial inoculation. Page 16 in: 2007 Annual Report of Project IP-5-Tropical and Grasses Legumes: Optimizing Genetic Diversity for Multipurpose Use. Centro Internacional de Agricultura Tropical (CIAT), Cali, Colombia.

22. Valério, J. R., Lapointe S. L., Kelemu., S., Fernandes C. D., and Morales, F. J. 1996. Pests and diseases of Brachiaria species. Pages 87-105 in: Brachiaria: Biology, Agronomy, and Improvement. J. W. Miles, B. L. Maas, and do Valle, C. B., eds. International Center for Tropical Agriculture, CIAT, Cali, Colombia. 